\title{
TIPE NEGARA TIMUR PURBA
}

\author{
Aditri Yudha Ghama Wanda \\ aditriyudhaghamawanda@gmail.com \\ 2010003600111 \\ UNIVERSITAS EKASAKTI
}

\section{A. PEndahuluan}

Sejarah telah mencatat bahwa setiap zaman mempunyai pemikiranpemikiran yang berbeda dan tokoh-tokoh yang berbeda mengenai cerita ketatanegaraan, ketika kita berbicara pada rana kenegaraan yang perlu kita ketahui adalah bagaimana menjadikan masyarakat sejahtera dan makmur, tanpa melepaskan sendi - sendi keutamaan sebuah negara itu berdiri, dan seperti yang kita ketahui Ketika para pendiri Bangsa (The founding fathers) mendesain model Negara Indonesia setelah merdeka lebih mengedepankan perdebatan mengenai dasar negara, bentuk negara (kesatuan atau federal), bentuk pemerintahan (kerajaan atau republik) dan ide/ cita Negara yang sedikit terkait dengan negara hukum dan pemerintahan yang demokrasi semua itu adalah persyaratan yang urgen dalam sebuah pembangunan negara dan menjadikan negara itu jelas dari tipe sejarah maupun dari kacamata hukum.

Seperti yang diteorikan oleh George Jellinek dan Jean Bodin bahwa Negara itu berdaulat yang dimana hukum ada karena adanya negara dan tiada satupun hukum yang berlaku jika tidak dikehendaki oleh negara. Dari teori tersebut kita bisa mengulas sebuah konsep bahwa negara itu adalah sistem yang betul -betul berkuasa terhadap kehidupan seluruh yang ada 
didalamnya demi mensejahterahkan rakyatnya. Negara terbentuk atas dasar pemikiran manusia seperti George Jellenik, jean Bodin, Rousseau, Diguit, Krabbe dan pemikir-pemikir lainnya, bahkan beberapa Filosof membuat konsep kemasyarakatan seperti Thales, Socrates, Plato, Aristoteles, dan lain - lain.

Dinilai dari segi sejarahpun konsep ketatanegaraanpun bermacam-macam ragam dan tipe pemerintahannya, maka dari itu makalah ini saya buat guna mempelajari ilmu negara secara universal dilihat dari segi sejarahnya dan dimakalah ini kami akan menggambarkan tipe - tipe negara untuk memenuhi tugas pada mata kuliah ilmu negara.

\section{B. PEMBAHASAN}

\section{a. Pengertian Tipe-Tipe Negara}

Menurut, R. Djoko Soetono : Negara adalah suatu organisasi atau asosiasi wilayah yang memiliki kekuatan individu dan daerah yang mengatur setiap kumpulan manusia - manusia yang berbeda dibawah suatu pemerintahan yang sama dengan terapan sistem hukum.

Bentuk atau Tipe negara adalah merupakan batas antara peninjauan secara sosiologis dan peninjauan secara yuridis mengenai negara. Peninjauan secara sosiologis jika negara dilihat secara keseluruhan (ganzhit) tanpa melihat strukturnya, sedangkan secara yuridis jika negaralpeninjauan dilihat dari strukturnya.

Machiavelli dalam bukunya II Prinsipe bahwa bentuk negara (hanya ada dua pilihan) jika tidak republik tentulah Monarkhi. Selanjutnya menjelaskan negara sebagai bentuk genus sedangkan Monarkhi dan republik sebagai bentuk speciesnya. 
Perbedaan dalam kedua bentuk Monarkhi dan republik (Jellinek, dalam bukunya Allgemene staatslehre) didasarkan atas perbedaan proses terjadinya pembentukan kemauan negara itu terdapat dua kemungkinan :

1. Apabila cara terjadinya pembentukan kemauan negara secara psikologis atau secara alamiah, yang terjadi dalam jiwa/badan seseorang dan nampak sebagai kemauan seseorang/individu maka bentuk negaranya adalah Monarkhi.

2. Apabila cara proses terjadinya pembentukan negara secara yuridis, secara sengaja dibuat menurut kemauan orang banyak sehingga kemauan itu nampak sebagai kemauan suatu dewan maka bentuk negaranya adalah republik.

\section{b. Sifat Khusus Negara}

Sifat khusus yang harus dimiliki dari pada suatu negara ada tiga yaitu sebagai berikut :

1. Memaksa

Sifat memaksa perlu dimiliki oleh suatu negara, agar peraturan perundangundangan ditaati sehingga penertiban dalam masyarakat dapat dicapai.

\section{Monopoli}

Negara mempunyai monopoli dalam menetapkan tujuan bersama dari masyarakat, Negara berhak melarang suatu aliran kepercayaan atau aliran politik tertentu hidup dan disebarluaskan kalau dianggap bertentangan dengan tujuan masyarakat.

3. Mencakup secara keseluruhan

Semua peraturan perundang-undangan berlaku untuk seluruh masyarakatnya.

\section{c. Fungsi dan Tujuan Negara}


Fungsi-fungsi negara secara umum adalah sebagai berikut :

1. Melaksanakan ketertiban Fungsi pelaksanaan ketertiban ini hadir untuk mengatur masyarakat agar tercipta kehidupan bernegara yang baik sesuai dengan tujuan dan citacita negara.

2. Fungsi kemakmuran dan kesejahteraan Fungsi ini makin penting seiring berjalannya waktu, terutama bagi negara yang menganut paham negara kesejahteraan (welfare staat). Dalam hal ini, negara berupaya agar masyarakat dapat hidup dan sejahtera, terutama dibidang ekonomi dan sosial masyarakat.

3. Fungsi pertahanan menjadi satu di antara fungsi yang sangat penting. Fungsi ini diperlukan untuk menjaga kemungkinan terjadinya serangan dari luar.

4. Fungsi keadilan Fungsi negara ini dilaksanakan oleh badan penegak hukum, khususnya badanbadan peradilan. Negara harus dapat menegakkan hukum secara tegas dan tanpa adanya unsur kepentingan tertentu.

Lima tujuan negara yang paling utama di antaranya, yaitu sebagai berikut :

1. Menciptakan keadaan agar rakyat bisa mencapai keinginan-keinginannya secara maksimal.

2. Memajukan kesusilaan manusia sebagai individu dan sebagai makhluk sosial.

3. Mencapai penghidupan dan kehidupan yang aman dan tenteram dengan taat kepada Tuhan. Pemimpin negara dalam menjalankan kekuasaannya berdasarkan kekuasaan Tuhan.

4. Berusaha menyelenggarakan ketertiban, keamanan, dan ketenteraman agar tercapai tujuan negara yang tertinggi, yaitu kemakmuran bersama. 
5. Memelihara dan menjamin terlaksananya hak-hak asasi manusia. Kemudian kekuasaan penguasa dibatasi oleh hak-hak asasi manusia.

\section{d. Tipe Negara Timur Purba}

Tipe negara timur purba ini bersifat tirani, monarkhi dan teokratis, raja berkuasa penuh atas segala keputusan atau aturan-aturan yang berlaku di kerajaannya tanpa adanya pertentangan dari masyarakat, penguasa (raja) berbuat sesuai kewenangannya, raja merangkap sebagai dewa oleh masyarakat. Kekuasaan raja ini bersifat absolut (mutlak). Turun temurun dan kepemimpinan raja sampai semur hidup.

Menurut Aristoteles sistem monarkhi dapat di bagi 3 yaitu :

1. Monarkhi Mutlak (absolut): Seluruh kekuasaan dan wewenang tidak terbatas (kekuasaan mutlak). Perintah raja merupakan undang-undang yang harus dilaksanakan. Kehendak raja adalah kehendak rakyat. Terkenal ucapan Louias ke-XIV dari Prancis: L'Etat cest moi (Negara adalah saya).

2. Monarkhi konstitusional ialah Monarkhi, di mana kekuasaan raja itu dibatasi oleh suatu Konstitusi (UUD). Raja tidak boleh berbuat sesuatu yang bertentangan dengan konstitusi dan segala perbuatannya harus berdasarkan dan sesuai dengan isi konstitusi.

3. Monarkhi parlementer ialah suatu Monarkhi, di mana terdapat suatu Parlemen (DPR), terhadap dewan di mana para Menteri, baik perseorangan maupun secara keseluruhan bertanggung jawab sepenuhnya.

Pada tipe negara timur purba sistem monarkhi yang dianut adalah Monarkhi mutlak.Ciri pokok Negara-negara timur kuno yaitu Negara yang didasarkan atas suatu paham keagamaan. Jika dilihat dari sudut kekuasaan maka Negara timur kuno adalah absolute, yaitu pemerintahan 
oleh raja-raja yang berkuasa secara sewenang-wenang. Tapi dalam kenyataanya raja-raja Negara timur kuno justru bertanggung jawab atas segala keburukan dan kebaikan rakyatnya, hal ini berbeda dengan ajaran Negara barat dengan istilah The King can do not wrong. Tipe negara-negara timur purba memiliki ciri-ciri sebagai berikut :

1. Bersifat teokratis (keagamaan), dimana suatu pemerintahan yang berdasarkan keagamaan, biasanya kepala negara dianggap dewa

2. Raja sebagai penguasa negara dianggap keturunan tuhan

3. Bersifat absolut (dispotisme), dimana seluruh putusan raja harus mutlak dijalankan dan disini pemerintahan tidak disokong oleh rakyat ataupun golongan.

4. Peradaban mesir kuno, mesopotamia, sumaria, babilonia

\section{PENUTUP}

Tipe negara ialah suatu penggolongan negara yang tidak mempunyai batas-batas yang tegas. Ini berbeda dengan klasifikasi negara atas bentuk-bentuk tertentu, misal bentuk negara (Kesatuan atau federasi) dan bentuk pemerintahan (Kerajaan atau Republik) dimana batasbatas dan ukurannya cukup tegas sehingga mudah dikenali. Menurut Prof. Logemann, tipe negara lebih berkenaan dengan struktur batin pemerintah, mengenai hubungan antara pemerintah dengan warga negara, dan mengenai tugas negara. Sifat khusus yang harus dimiliki dari pada suatu negara ada tiga yaitu sebagai berikut :

1. Memaksa

2. Monopoli

3. Mencakup secara keseluruhan

Fungsi-fungsi negara secara umum: 
1. Melaksanakan ketertiban

2. Fungsi kemakmuran dan kesejahteraan

3. Fungsi pertahanan

4. Fungsi keadilan

Lima tujuan negara yang paling utama di antaranya, yaitu sebagai berikut:

1. Menciptakan keadaan agar rakyat bisa mencapai keinginan-keinginannya secara maksimal.

2. Memajukan kesusilaan manusia sebagai individu dan sebagai makhluk sosial.

3. Mencapai penghidupan dan kehidupan yang aman dan tenteram dengan taat kepada Tuhan. Pemimpin negara dalam menjalankan kekuasaannya berdasarkan kekuasaan Tuhan.

4. Berusaha menyelenggarakan ketertiban, keamanan, dan ketenteraman agar tercapai tujuan negara yang tertinggi, yaitu kemakmuran bersama.

5. Memelihara dan menjamin terlaksananya hak-hak asasi manusia. Kemudian kekuasaan penguasa dibatasi oleh hak-hak asasi manusia.

Tipe negara-negara timur purba memiliki ciri-ciri sebagai berikut :

1. Bersifat Teokrasi, menerapkan gaagasan kedaulatan tuhan

2. Raja sebagai penguasa negara dianggap keturunan tuhan

3. Kepemimpnan cenderung absolut

4. Peradaban mesir kuno, mesopotamia, sumaria, babilonia

\section{DAFTAR PUSTAKA}


Laurensius Arliman S, Penguatan Perlindungan Anak Dari Tindakan Human Trafficking Di Daerah Perbatasan Indonesia, Jurnal Selat, Volume 4, Nomor 1, 2016.

Laurensius Arliman S, Problematika Dan Solusi Pemenuhan Perlindungan Hak Anak Sebagai Tersangka Tindak Pidana Di Satlantas Polresta Pariaman, Justicia Islamica, Volume 13, Nomor 2, 2016.

Laurensius Arliman S, Pelaksanaan Perlindungan Anak Yang Tereksploitasi Secara Ekonomi Oleh Pemerintah Kota Padang, Veritas et Justitia, Volume 2, Nomor 1, 2016.

Laurensius Arliman S, Kedudukan Ketetapan MPR Dalam Hierarki Peraturan PerundangUndangan Di Indonesia, Lex Jurnalica, Volume 13, Nomor 3, 2016.

Laurensius Arliman S, Komnas Perempuan Sebagai State Auxialiary Bodies Dalam Penegakan Ham Perempuan Indonesia, Justicia Islamica, Volume 14, Nomor 2, 2017.

Laurensius Arliman S, Peranan Pers Untuk Mewujudkan Perlindungan Anak Berkelanjutan Di Indonesia, Jurnal Ilmu Hukum Tambun Bungai, Volume 2, Nomor 2, 2017.

Laurensius Arliman S, Mewujudkan Penegakan Hukum Yang Baik Untuk Mewujudkan Indonesia Sebagai Negara Hukum, Jurnal Hukum Doctrinal, Volume 2, Nomor 2, 2017. 
Laurensius Arliman S, Participation Non-Governmental Organization In Protecting Child Rights In The Area Of Social Conflict, The 1st Ushuluddin and Islamic Thought International Conference (Usicon), Volume 1, 2017.

Laurensius Arliman S, Partisipasi Masyarakat Dalam Pembentukan Perundang-Undangan Untuk Mewujudkan Negara Kesejahteraan Indonesia, Jurnal Politik Pemerintahan Dharma Praja, Volume 10, Nomor 1, 2017, https://doi.org/10.33701/jppdp.v10i1.379.

Laurensius Arliman S, Peran Komisi Perlindungan Anak Indonesia Untuk Mewujudkan Perlindungan Anak, Jurnal Respublica Volume 17, Nomor 2, 2018.

Laurensius Arliman S, Menjerat Pelaku Penyuruh Pengrusakan Barang Milik Orang Lain Dengan Mempertimbangkan Asas Fungsi Sosial, Jurnal Gagasan Hukum, Volume 1, Nomor 1, 2019.

Laurensius Arliman S, Ilmu Perundang-Undangan Yang Baik Untuk Negara Indonesia, Deepublish, Yogyakarta, 2019.

Laurensius Arliman S, Isdal Veri, Gustiwarni, Elfitrayenti, Ade Sakurawati, Yasri, Pengaruh Karakteristik Individu, Perlindungan Hak Perempuan Terhadap Kualitas Pelayanan Komnas Perempuan Dengan Kompetensi Sumber Daya Manusia Sebagai Variabel Mediasi, Jurnal Menara Ekonomi: Penelitian dan Kajian Ilmiah Bidang Ekonomi, Volume 6, Nomor 2, 2020. 
Laurensius Arliman S, Pendidikan Kewarganegaraan, Deepublish, Yogyakarta, 2020.

Laurensius Arliman S, Makna Keuangan Negara Dalam Pasal Pasal 23 E Undang-Undang Dasar 1945, Jurnal Lex Librum, Volume 6, Nomor 2 Juni 2020, http://dx.doi.org/10.46839/1ljih.v6i2.151.

Laurensius Arliman S, Kedudukan Lembaga Negara Independen Di Indonesia Untuk Mencapai Tujuan Negara Hukum, Kertha Semaya Journal Ilmu Hukum, Volume 8, Nomor 7, 2020.

Laurensius Arliman S, Pelaksanaan Assesment Oleh Polres Kepulauan Mentawai Sebagai Bentuk Pelaksanaan Rehabilitasi Bagi Pecandu Dan Korban Penyalahgunaan Narkotika, Jurnal Muhakkamah, Volume 5, Nomor 1, 2020.

Laurensius Arliman S, Aswandi Aswandi, Firgi Nurdiansyah, Laxmy Defilah, Nova Sari Yudistia, Ni Putu Eka, Viona Putri, Zakia Zakia, Ernita Arief, Prinsip, Mekanisme Dan Bentuk Pelayanan Informasi Kepada Publik Oleh Direktorat Jenderal Pajak, Volume 17, No Nomor, 2020.

Larensius Arliman S, Koordinasi PT. Pegadaian (Persero) Dengan Direktorat Reserse Narkoba Polda Sumbar Dalam Penimbangan Barang Bukti Penyalahgunaan Narkotika, UIR Law Review, Volume 4, Nomor 2, 2020, https://doi.org/10.25299/uirlrev.2020.vol4(1).3779. 
Laurensius Arliman S, Tantangan Pendidikan Kewarganegaraan Pada Revolusi 4.0, Ensiklopedia Sosial Review, Volume 2, Nomor 3, 2020.

Muhammad Afif dan Laurensius Arliman S, Protection Of Children's Rights Of The Islamic And Constitutional Law Perspective Of The Republic Of Indonesia, Proceeding: Internasional Conference On Humanity, Law And Sharia (Ichlash), Volume 1, Nomor 2, 2020.

Otong Rosadi danLaurensius Arliman S, Urgensi Pengaturan Badan Pembinaan Idelogi Pancasila Berdasarkan Undang-Undang Sebagai State Auxiliary Bodies yang Merawat Pancasila dalam Perspektif Hak Asasi Manusia, Prosiding Konferensi Nasional Hak Asasi Manusia, Kebudayaan dan Tujuan Pembangunan Berkelanjutan Indonesia pada Masa Pandemi Covid-19: Tantangan untuk Keilmuan Hukum dan Sosial Volume 1, Universitas Pancasila, Jakarta, 2020. 